\title{
THE WORLD DF INNOVATION
}

https://doi.org/10.15407/scine17.05.095

DEMURA, M. ${ }^{1}$ (https://orcid.org/0000-0002-5637-3290), and KLEPKA, D. ${ }^{2}$ (https://orcid.org/0000-0001-8423-4581)

'Yaroslav Mudryi National Law University, 77, Pushkinskaya str., Kharkiv, 61024, Ukraine, +380 57 704 9293, kancel@nulau.edu.ua

${ }^{2}$ Academician Stashis Scientific Research Institute for the Study of Crime Problems, National Academy of the Law Sciences of Ukraine, 49, Pushkinskaya str., Kharkiv, 61022, Ukraine, +380 57715 6208, officemanager@aprnu.rol.net.ua

\section{USING ARTIFICIAL INTELLIGENCE ALGORITHMS IN THE FIELD OF CRIMINAL JUDICIARY: INTERNATIONAL EXPERIENCE AND DOMESTIC PROSPECTS}

Introduction. The world has been currently experiencing a new technological revolution, the key element of which is the transmission, processing, and use of information. One of the directions of this revolution is the development and application of artificial intelligence (AI) science in various fields.

Problem Statement. International experience in the use of artificial intelligence algorithms in the field of criminal justice and national prospects for its use.

Purpose. The purpose is to study the international experience in the use of AI algorithms in the field of criminal justice and to identify possible directions for the introduction of such technologies in the domestic criminal process.

Materials and Methods. The methodological framework is the dialectical, systemic, logical methods, as well as the law comparison method.

Results. The analysis of national and foreign criminal procedural legislation, as well as the practice of using AI in the field of criminal procedure has shown the possibilities of using AI algorithms in the field of criminal justice. It has been proved that, given the international experience, the introduction of AI algorithms in criminal proceedings in Ukraine is not only a promising, but in some cases, a necessary tool to ensure the rights and legitimate interests of participators in criminal proceedings. At the same time, the most important issue is the observance of individual rights when using AI algorithms, as well as ensuring a fair trial so that everyone who has committed a criminal offense is brought to justice, no innocent person has been accused or convicted, no person has been subjected to unreasonable procedural coercion, and that proper legal procedure is applied to each participator in the criminal proceedings.

Conclusions. The use of AI may significantly reduce the burden on pre-trial investigation bodies, prosecutor's office, and judicial system in general. In addition to proper technical support for the use of AI algorithms in criminal proceedings in Ukraine, it is also necessary to introduce adequate and high-quality regulations for the use of such technologies in criminal proceedings.

Keywords: artificial intelligence, criminal process, algorithms, pre-trial investigation, and information.

Citation: Demura, M., and Klepka, D. Using Artificial Intelligence Algorithms in the Field of Criminal Judiciary: International Experience and Domestic Prospects. Sci. innov. 2021. V. 17, no. 5. P. 95-101. https:// doi.org/10.15407/scine17.05.095 
Artificial intelligence is new electricity.

Very soon, the neural nets will penetrate into all spheres of life

Sundar Pichai

Today, the world has been experiencing a new technological revolution, a key element of which is the transmission, processing, and use of information. We are witnessing the emergence of a new society - the information one that is based on the networking the mankind intellectual resources. All this leads not only to transformations of the economic and social conditions of life, but also to a new philosophy of life and ways of the world civilization development. Like other technological revolutions (the invention of the internal combustion engine or electricity), the new revolution forces us to rethink many established archetypes of behavior and management and to build a variety of futurological predictions and alternative estimates [1]. One of the directions of such a revolution is the development and application of artificial intelligence (hereinafter, $\mathrm{AI}$ ) science in various fields. Today, AI is globally used in medicine, economics, military industry, and in such a seemingly conservative sphere of public relations as criminal procedural relations.

At the same time, it should be noted that in our country, the use of AI in the field of criminal justice is at the nascent stage. However, given that the Ministry of Digital Transformation of Ukraine has established an expert committee and developed a concept for the development of AI in Ukraine, a comparative analysis of the use of AI in criminal proceedings in different countries is an important research task. In this regard, the purpose of this research is to study the international experience of using AI algorithms in the field of criminal justice and to identify possible directions for the introduction of such technologies in the domestic criminal process.

AI is a metaphorical concept to denote: the system of man-made tools that reproduce certain functions of human thinking; the areas of research, the purpose of which is to create engineering sys- tems capable of solving non-computational problems and to perform actions that require the processing of meaningful information and are considered the human brain prerogative. Such tasks are, for example, to prove theorems, to solve game problems (playing chess), to translate from one language to another, to create music, to recognize visual images, to solve complex creative problems of science and social practice. One of the important tasks of $\mathrm{AI}$ is to create intelligent robots that can autonomously perform operations to achieve human goals and to adjust their actions [2, 24].

There are the three types of AI: 1 ) weak $\mathrm{AI}$ is an intelligence focused on solving one or more tasks that is or may be performed by a human being. Recently, weak AI has been increasingly called the applied AI; 2) strong AI is an intellect focused on solving all tasks that are or may be performed by a human being; 3) artificial superintelligence is intelligence that is much smarter than the best human intelligence in almost every field, including scientific creativity, general wisdom, and social skills [3, 157-158].

It is interesting to note that the weighted average forecasts for the emergence of Artificial Superintelligence (ASI) are as follows: usually, the technologies that have already existed improve for 5-10 years; those that are today at the level of laboratory research are implemented in 1520 years. Most likely, it is necessary to make an adjustment for the persistent acceleration (as compared with the past centuries and decades) of the information exchange and the development of economic relations, which may mean a more rapid formation of the digital future [4, 154].

According to data published in 2017 by the Technology Review, AI will reach $10 \%$ of the human intellect in $2022,50 \%$ in 2040 , and by 2075 , the thinking processes of $\mathrm{AI}$ and human being will be indistinguishable.

However, today, in terms of some indicators, human intelligence is inferior to artificial. This thesis may be illustrated on the basis of a demonstration experiment in which the lawyers (professors of law from Stanford and the University of 
Southern California) compete with AI developed by LawGeex legal AI platform, which is able to read and to interpret complex legal documents. The professors scored $85 \%$, but they completely lost a battle to AI that gained $95 \%$. In addition, the average human being needs 92 minutes to analyze the documents, while the AI does this job for 26 seconds [5].

Of course, such results do not give a fair evaluation of the intelligence level and should not be interpreted unambiguously. However, it should be recognized that in general the potential of such systems is extremely high and there are reasons to talk about the use of AI in various areas of law, including criminal procedure. According to the researchers, in jurisprudence, "robots will take your work, not your jobs," i.e. robots shall do routine operations, but shall not take jobs from people [6].

For the convenience of studying the international experience in the use of AI in criminal proceedings, we propose to group it into the several areas: 1) the prevention of criminal offenses; 2) the use in pre-trial investigation; and 3) the use at the trial stage.

The prevention of criminal offenses. This direction is implemented through the use of numerous information tools to prevent criminal acts (by identifying possible places where this may happen, or their potential participators). This vector includes "precautionary police control" tools used to prevent certain types of offenses with elements of regularity, such as burglary, street violence, vehicle theft /carjacking. These tools are used based on their ability to pinpoint exactly where and when these crimes may be committed and to reproduce this information on a map as hot spots to be monitored in real time by police patrols. This process is called prognostic mapping of crime [7].

For example, in Italy, in the city of Trento, from November 2012 to May 2015, the project Electronic security: information and communication technologies for knowledge-based and predictable urban security was implemented. This project aimed at preventing crime and enhancing secu- rity in the city. The project used a database that collected information on crimes known to the police, the results of victimization survey conducted by the city administration, data on real safety and its perception by citizens, information on urban riots obtained from the police, and other parameters related to the "smart city" (for example, information concerning the socio-demographic context, the urban environment, night lighting, surveillance cameras, public transport, etc.). The project leaders confirmed the reliability of the used methods that allowed predicting criminal acts with a success rate of about $60-65 \%$ and helped to increase the effectiveness of fight against crime with the use of limited resources [8].

Similar projects have been implemented in the United Kingdom as part of a pilot project to predict possible sites of burglary, theft, and attacks with the help of AI. They have shown that the used software projections called PREDPOL come true in $78 \%$ of cases, as compared with $51 \%$ of the predictions made with the use of conventional methods.

According to the European Ethical Charter on the use of AI in the judicial systems and their environment, a fairly widespread and well-known tool for the use of AI, which aims at preventing criminal offenses or the so-called tool of preventive policing is the travel ban list based on big data analysis, which collects and analyzes the data on potential terrorists in order to prevent the commission of terrorist acts or the algorithms used to detect fraud or money laundering [7].

The use in pre-trial investigation. In criminal proceedings, AI is widely used in the course of pre-trial investigation, when law enforcement agencies already have information about criminal offense and need to analyze a large amount of data. For example, such tools as Connect that is used by the British police to analyze huge amounts of data obtained during financial transactions to identify correlations or schemes of transactions or the International Database on Child Sexual Exploitation (ICSE DB) run by Interpol, which helps to identify victims and/or criminals by ana- 
lyzing, for example, furniture and other objects in images of violence or background noise on video have proved themselves particularly effective in combating crime. Connect enables searching large amounts of data with a very high level of complexity, which previously took months and now may be performed in minutes, with a high accuracy of results.

In addition, there is experience of the use of AI in making decision whether to register an application or report on a criminal offense in Spain. For example, the researchers from the Charles III University of Madrid and the University of Cardiff in Wales have developed the AI algorithm, VeriPol that is able to detect false reports to the police based on an analysis of their content. This technology was tested by the Spanish police in 2017. In particular, the investigators checked the AI's findings in the course of personal meetings with the applicants. It was interesting that in $83 \%$ of cases, the applicant's versions were not confirmed and the proceedings were closed [9].

The United States, as one of the leading users of AI in justice, has been using such technologies when choosing a pre-trial restriction. For example, the researchers at Stanford University (Stanford Computational Policy Lab) have developed an algorithm that assists judges in choosing detention or bail as pre-trial restriction for a defendant. Having reviewed about 100,000 procedural documents related to the choice of pre-trial restriction, the developers found that some judges in $90 \%$ of cases released defendants on bail, while others did so only $50 \%$. The program enables the fair assessment of risks, so detention is chosen for a much smaller number of people [10].

The use at the trial stage. An example of the use of AI at the trial stage is a project proposed by a joint team of experts from the Universities of Pennsylvania and Sheffield. Within the project, an AI algorithm that is able to make decisions on the case has been created. For its development, algorithms for analyzing 584 cases of the European Court of Human Rights (hereinafter, the ECHR), which concern the use of torture, humi- liation, determination of the fairness of court decision and so on have been used. The study has showed that the AI verdict coincides with the decision of the ECHR in 79\% of cases [11].

In addition, at the trial stage, judges may use AI and its tools to "predict" the recurrence of a crime. These tools are programs for assessing the likelihood of repeated commission of offence, i.e. predicting the behavior of a sentenced person and the consequences of imposing a sentence (for example, if a non-custodial sentence is imposed, is it sufficient to prevent the person from committing a new crime?).

At the same time, the European Commission on the Efficiency of Justice has noted that the use of "forecasting" tools or "algorithmic justice", "automated justice", "imitation of justice" by judges in criminal proceedings is very rare in Europe [7], unlike in the United States, where it is rather popular. The United States invested in these tools both in civil and criminal proceedings (for example, COMPAS algorithms or RAVEL LAW or ROSS chatbot tools), and as early as in 2015, the law enforcement agencies had about 50 forecasting methods based on the use of digital technologies and AI [7].

A prerequisite for the introduction of $\mathrm{AI}$ in Ukraine is the launch of a unified judicial information and telecommunications system (UJITS). In general, the system provides completely paperless record-keeping by using electronic digital signature and electronic document control, creating personal offices to perform any procedural actions, as well as improvement of the unified state register of court decisions through adding to it a system of hyperlinks to legal determinations of the Supreme Court, which allows the algorithm to select the decision of the Supreme Court relevant to the specific case and to draft a decision without human involvement. It is quite possible that in the future minor disputes may be resolved online, with the use of the AI system, which significantly relieves the courts [10].

In addition, the possibility of introducing AI algorithms for choosing a pre-trial restriction has 


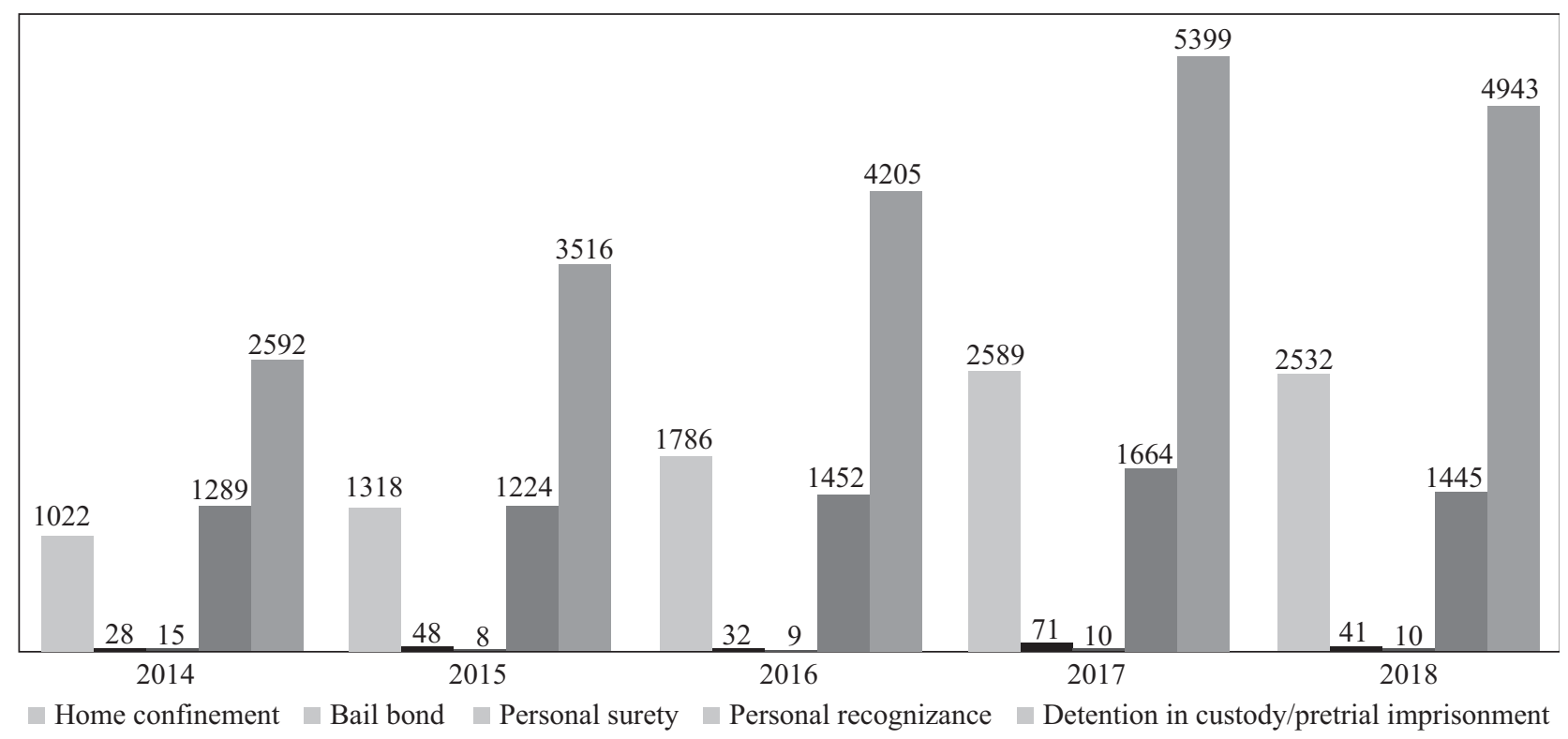

Fig. 1. Statistical analysis of decisions of investigating judges on the imposition, change or cancellation of pre-trial restrictions in $2014-2018$

been widely discussed in the national legal com- $j$ munity. Given the shortcomings of such technology, which have been noted by the lawyers and researchers, we consider it necessary to pay attention to some positive aspects.

It is seen that the choice of a pre-trial restriction with the use of AI algorithms may significantly improve the quality of procedural documents of the prosecution, namely the investigator/ prosecutor request for a pre-trial restriction. As the analysis of law enforcement practice has shown, in most cases such requests contain only formal references to the risks provided for in $\mathrm{Cl}$. 177 of the CPC of Ukraine, which are not substantiated by factual data. At the same time, investigating judges, while considering such requests, put the interests of criminal proceedings above the interests of a defendant and satisfy the requests in $90 \%$ of cases. Therefore, the use of AI is assumed to helps avoid the subjective factor and to analyze the request of investigator/prosecutor for a pre-trial restriction in unbiased manner, solely on the basis of the CPC of Ukraine and the algorithm. In addition, we believe that the use of AI while choosing a pre-trial restriction helps to avoid the judicial practice according to which in Ukraine the severest restriction at the stage of pre-trial investigation - detention - is used most often.

To support this assumption, we can cite the results of statistical analysis of court decisions for 2014-2018, concerning the choice, change or cancellation of pre-trial restriction in criminal proceedings, which indicate that detention is the most common type of restriction in general and for the vast majority of crime categories, despite the fact that it is the exclusive and severest restriction (Fig. 1) [12].

At the same time, while talking about the introduction of AI algorithms in the criminal justice system, we cannot ignore the issue of proper legal regulation of such actions. In this regard, it is worth paying attention to the European Ethical Charter on the use of $\mathrm{AI}$ in the judicial systems and their environment as adopted by the European Commission for the Efficiency of Justice of the Council of Europe, in 2018. This document defines the five core principles for the use of $\mathrm{AI}$ in justice: 1) principle of respect for fundamental rights; 2) principle of non-discrimination: specifically prevent the development or intensifica- 


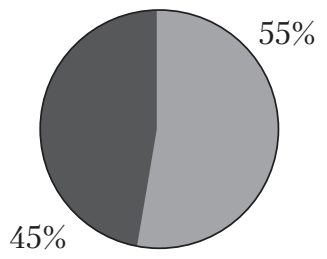

Appel against other type of investigator/prosecutor inaction

Appeal against investigator/prosecutor inaction (failure to record data into the URPTI)

Fig. 2. Statistical analysis of decisions of investigating judges upon the investigation of complaints in accordance with the procedure of par. 1 Section 1 Clause 303 of the CPC of Ukraine

tion of any discrimination between individuals or groups of individuals; 3) principle of quality and security: with regard to the processing of judicial decisions and data, use certified sources and intangible data with models elaborated in a multi-disciplinary manner, in a secure technological environment; 4) principle "under user control" preclude a prescriptive approach and ensure that users are informed actors and in control of the choices made; 5) principle of transparency, impartiality and fairness. It is expected that similar provisions will be introduced to the Ukrainian criminal procedural law in the future.

Particular attention should be paid to the pilot project of the eCase electronic criminal proceedings system launched on April 20, 2020, in the anti-corruption bodies. eCase provides the full automation of today's paperwork, which provides benefits for all participants in criminal proceedings. The Prosecutor's Office will monitor the progress of the investigation and perform procedural guidance online. The investigators will promptly receive and be able to analyze all the necessary data, since the system updates all the information at each stage, plans time-management and keeps calendar of assignments. Witnesses, suspects, and their representatives will also receive the necessary documents in electronic format. Judges will have access to the system even in the course of court trial for the further examination of evidence and key positions in the proceedings [13]. Such a project may be considered a basis for the further implementation of AI algorithms in the procedural activities of pre-trial investigation bodies, prosecutor's office.

We believe that the introduction of verification of statements and reports of criminal offenses with the use of AI, such as VeriPol algorithm mentioned above, is of particular importance in today's realities. We have analyzed 250 decisions of investigative judges in Kharkiv Oblast on the inaction of the investigating prosecutor in the course of pre-trial investigation (paragraph 1, part 1 of Clause 303 of the CPC of Ukraine). The results of the analysis are presented in Fig. 2. It should be noted that in most cases, complaints about the inaction of investigator/prosecutor, which is failure to enter information into the Unified Register of Pre-Trial Investigations are satisfied by the investigating judges.

From the above it may be reasonably concluded that the introduction of AI algorithms in the verification of statements and reports of criminal offenses will result in avoiding unjustified refusals to register the statements in the URPTI and, consequently, will significantly reduce the burden on the judiciary system.

Based on the above, it is seen that given the international experience, the introduction of AI algorithms in criminal proceedings in Ukraine is not only promising, but also, in some cases, a necessary tool to ensure the rights and legitimate interests of participants in criminal proceedings. In addition, the use of AI may significantly reduce the burden on pre-trial investigation bodies, prosecutor's office, and the judicial system in general. However, the most important issue is the observance of rights of individuals when using $\mathrm{AI}$ algorithms, as well as ensuring a fair trial so that everyone who has committed a criminal offense is prosecuted to the extent of his/her guilt, no innocent person is been charged or convicted, no person has been subjected to unreasonable procedural restriction, and that a proper legal procedure is applied to each participant in the criminal proceedings (Clause 2 of the CPC). Therefore, in addition to proper technical support for the use of AI algorithms in criminal proceedings in Ukraine, it is also necessary to introduce adequate and high-quality regulations for the use of such technologies in criminal proceedings. 


\section{REFERENCES}

1. Yatskiv, V. M. Global Technological Revolution - 2020 (based on the report of the RAND Corporation) URL: http://ena. lp.edu.ua:8080/bitstream/ntb/19170/1/11-Yatskiv-60-63.pdf [in Ukrainian] (Last accessed: 22.07.2020).

2. Yasnytskyi, L. N. (2008). Introduction to Artificial Intelligence. Moscow: Publishing Center "Academy". 176 p. [in Russian].

3. Bondarenko, A. O. (2018). Criminal threat of artificial intelligence. Legal scientific electronic journal, 1, 156-157. URL: http://lsej.org.ua/1_2018/44.pdf [in Ukrainian] (Last accessed: 22.07.2020).

4. Raduzhnyi, O. E. (2018). Artificial intelligence, information security and lawmaking process (criminal law aspect). Information and law. 1(24), 149-158. URL: http://ippi.org.ua/sites/default/files/18_3.pdf [in Ukrainian] (Last accessed: 22.07.2020).

5. Kudriavtsev, N. Artificial intelligence understands legal contracts better than lawyers. URL: https://www.popmech.ru/ technologies/news-412712-iskusstvennyy-intellekt-luchshe-yuristov-razbiraetsya-v-yuridicheskih-kontraktah/ [in Russian] (Last accessed: 22.07.2020).

6. Biakhov, O. Jurisprudence and artificial intelligence: an era of unprecedented challenges is coming. Materials of a closed expert discussion of the Valdai Club and RVCJSC "Jurisprudence: what awaits the law in the era of robots and artificial intelligence?” URL: http://ru.valdaiclub.com/events/posts/articles/yurisprudentsiya-i-iskusstvennyy-intellekt-nastupaetepokha-bespretsedentnykh-vyzovov/ [in Russian] (Last accessed: 22.07.2020).

7. European ethical Charter on the use of Artificial Intelligence in judicial systems and their environment Adopted at the 31st plenary meeting of the CEPEJ (Strasbourg, 3-4 December 2018) URL: https://rm.coe.int/ethical-charter-en-forpublication-4-december-2018/16808f699c (Last accessed: 22.07.2020).

8. Esecurity.trento. URL: http://www.esecurity.trento.it/ (Last accessed: 22.07.2020).

9. Scientists from Wales and Spain developed software that was so effective that it was adopted by the Spanish police. The VeriPol algorithm determines which police statements are not worth the effort.. URL: https://hightech.plus/2018/10/29/ ii-detektor-lzhi-vichislyaet-vruna-po-ego-pismam [in Russian] (Last accessed: 20.04.2020).

10. Artificial intelligence in justice. URL: https://cedem.org.ua/analytics/shtuchnyj-intelekt-pravosuddia/ [in Ukrainian] (Last accessed: 20.04.2020).

11. Artificial intelligence was taught to predict court decisions in cases of human rights violations. URL: https://habr.com/ ru/post/398519/ [in Russian] (Last accessed: 20.04.2020).

12. Statistical analysis of the application of precautionary measures by courts, 2014-2018. URL: https://socialdata.org.ua/ statistichniy-analiz-zastosuvannya-su/ [in Ukrainian] (Last accessed: 20.04.2020).

13. The e-criminal system eCase will be launched on April 30. URL: https://legalhub.online/kryminalne-pravo/systemuelektronnogo-kryminalnogo-provadzhennya-ecase-zapustyat-vzhe-30-kvitnya/ [in Ukrainian] (Last accessed: 20.04.2020).

Received 18.08.2020

Revised 18.03.2021

Accepted 09.04.2021

М.I. Демура ${ }^{1}$ (https://orcid.org/0000-0002-5637-3290),

Д.І. Клепка ${ }^{2}$ (https://orcid.org/0000-0001-8423-4581)

${ }^{1}$ Національний юридичний університет імені Ярослава Мудрого, вул. Пушкінська, 77, Харків, 61024, Україна,

+38057 704 9293, kancel@nulau.edu.ua

${ }^{2}$ Науково-дослідний інститут вивчення проблем злочинності

імені академіка В.В. Сташиса Національної академії правових наук України,

вул. Пушкінська, 49, Харків, 61002, Україна,

+380 57715 6208, officemanager@aprnu.rol.net.ua

\section{ВИКОРИСТАННЯ АЛГОРИТМІВ ШТУЧНОГО ІНТЕЛЕКТУ \\ У ГАЛУЗІ КРИМІНАЛЬНОГО СУДОЧИНСТВА: МІЖНАРОДНИЙ ДОСВІД ТА ВІТЧИЗНЯНІ ПЕРСПЕКТИВИ}

Вступ. Наразі світ переживає чергову технологічну революцію, ключовим елементом якої є передача, обробка та використання інформації. Одним з напрямів такої революції є розвиток та застосування у різних галузях науки штучного інтелекту (Ш). 
Проблематика. Міжнародний досвід використання алгоритмів штучного інтелекту у галузі кримінального судочинства та національні перспективи його використання.

Мета. Дослідження міжнародного досвіду використання алгоритмів ШІ у галузі кримінального судочинства та визначення можливих напрямів впровадження таких технологій у вітчизняний кримінальний процес.

Матеріали й методи. Методологічною основою слугували діалектичний, системний, логічний методи, а також метод порівняльного правознавства.

Результати. Аналіз національного та зарубіжного кримінального процесуального законодавства, а також практики використання ШІ показав можливості використання алгоритмів ШІ у галузі кримінального судочинства. Доведено, що, враховуючи міжнародний досвід, запровадження використання алгоритмів ШІ у кримінальному провадженні України має не тільки свої перспективи, а в деяких випадках навіть є необхідним інструментом забезпечення прав та законних інтересів учасників кримінального провадження. Найважливішим при цьому залишається питання дотримання прав особи під час використання алгоритмів ШІ, а також забезпечення справедливого судового розгляду з тим, щоб кожний, хто вчинив кримінальне правопорушення, був притягнутий до відповідальності в міру своєї вини, жоден невинуватий не був обвинувачений або засуджений, жодна особа не була піддана необгрунтованому процесуальному примусу і щоб до кожного учасника кримінального провадження була застосована належна правова процедура.

Висновки. Використання ШІ може суттєво зменшити навантаження як на органи досудового розслідування, прокуратуру, так і на судову систему загалом. Окрім належного технічного забезпечення використання алгоритмів Ш у кримінальному провадженні України, необхідним є також запровадження належного та якісного нормативного регулювання використання таких технологій у кримінальному провадженні.

Ключові слова: штучний інтелект, кримінальний процес, алгоритми, досудове розслідування, технології, інформація. 